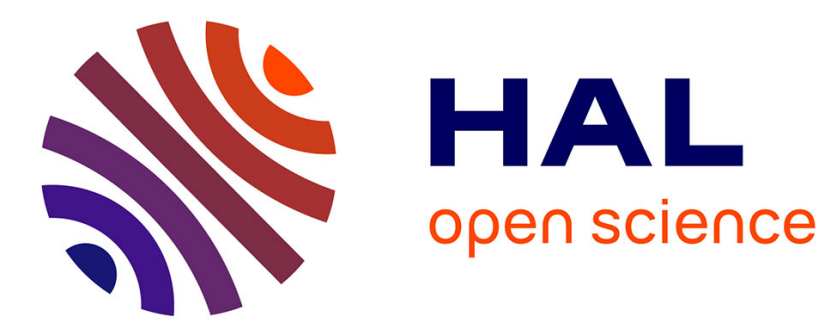

\title{
New sources of animal proteins: cultured meat
}

\author{
Mark Post, Jean-François J.-F. Hocquette
}

\section{To cite this version:}

Mark Post, Jean-François J.-F. Hocquette. New sources of animal proteins: cultured meat. New aspects of meat quality - from genes to ethics, Woodhead Publishing Limited, 2017, 10.1016/B9780-08-100593-4.00017-5 . hal-01603257

\section{HAL Id: hal-01603257 \\ https://hal.science/hal-01603257}

Submitted on 5 Jun 2020

HAL is a multi-disciplinary open access archive for the deposit and dissemination of scientific research documents, whether they are published or not. The documents may come from teaching and research institutions in France or abroad, or from public or private research centers.
L'archive ouverte pluridisciplinaire HAL, est destinée au dépôt et à la diffusion de documents scientifiques de niveau recherche, publiés ou non, émanant des établissements d'enseignement et de recherche français ou étrangers, des laboratoires publics ou privés.

\section{다(1)(2)}

Distributed under a Creative Commons Attribution - ShareAlikel 4.0 International 


\title{
Chapter 16
}

\section{New Sources of Animal Proteins: Cultured Meat}

\author{
M.J. Post* and J.-F. Hocquette**,† \\ *Maastricht University, Maastricht, The Netherlands; **INRA, UMR1213 Herbivore, Saint Genès \\ Champanelle, France; ${ }^{\dagger}$ Clermont Université, VetAgro Sup, UMR1213 Herbivore, Saint Genès \\ Champanelle, France
}

\section{INTRODUCTION}

Mankind has been consuming meat perhaps for 1.5 million years and it has greatly benefited us. Over time however, the cultural and nutritional necessities have changed and they will continue to change. The current balanced view of the people in developed nations on meat consumption is that although the vast majority of consumers eat meat, it comes at a high price. It is recognized that livestock meat production puts pressure on crop output and comes with an appreciable burden on the environment through greenhouse gas emission (FAO, 2011) At the same time, societal acceptance of intensified livestock breeding and herding with perceived deterioration of animal welfare is dwindling. It is also questionable if we can increase livestock meat production with the same livestock farming systems to match the projected $70 \%$ increase in demand over the coming decades.

Against this background, several alternative protein sources as well as alternative meat production systems are being explored. Alternative protein sources are of vegetable, grain, fungal, algal, or insect origin. The nutritional value and the life cycle of these nonmeat proteins vary tremendously, but they have in common that neither of them produces the same tissue that consumers recognize as meat even if some efforts are continuously made to mimic the taste and shape of meat. Success of these alternatives therefore depends on the extent to which they can replace meat as a staple and highly appreciated part of the diet. Culturing meat from skeletal muscle and fat tissue precursor cells aims to reproduce a muscle tissue which may be transformed into meat through alternative, production methods that are potentially more resource efficient and environmentally friendly according to some authors. However, such a disembodied 
production method also faces the challenge of public acceptance, as it may not be perceived as being natural, healthy, or safe. The context of the discussion in this chapter is the production of a biomimetic, that is, meat that is the closest possible match to livestock beef.

The uncertainties of the future of meat consumption and production and the uncertainties linked with alternative protein sources dictate comprehensive multidisciplinary research and development in every possible solution to a problem that is both tangible and serious.

In this chapter, we discuss alternative production methods of meat and culturing beef in particular. The choice for beef is rational as this meat is least efficiently produced through livestock and is also associated with the highest green house gas emission per kilogram.

\section{TECHNOLOGY}

Techniques to culture tissue including skeletal muscle have quite recently been developed in a new medical field called regenerative medicine. The goal of this endeavor is to replace dysfunctional of dysmorphic tissue by newly cultured and fully functional tissue from patient's own cells. The originating cells may be stem cells, typically adult stem cells that are tissue specific, or can be derived from tissues that consist of cells that retain replicative capacity.

To grow de novo muscle tissue and perhaps other components of meat, such as fat and connective tissue, three basic components are required:

1. tissue specific cells with replicative capacity,

2. a biomaterial that at least temporarily keeps cells in a tissue configuration, and

3. a bioreactor to feed the tissue and to provide mechanical and biochemical stimuli for optimal differentiation of the tissue culture.

The same conditions also apply to culturing meat for the purpose of consumption.

Meat consists mostly of skeletal muscle cells and because mature skeletal muscle cells no longer proliferate, stem cells are the only possible source of replication-competent precursors. Fortunately, after the discovery of myoblasts in skeletal muscle, it was proven that they are the bona fide muscle stem cells in that they can self-renew and repair damaged muscle tissue (Seale et al., 2000). Since then, it has been shown that this group of cells, identified on the basis of Pax7 and CD56 positivity, is in fact a heterogeneous group (Motohashi and Asakura, 2014). The practical implication of this heterogeneity is as yet unknown. By well-described and relatively simple methods, myoblasts can be harvested from a fresh piece obtained by a transcutaneous needle biopsy of a cow muscle (Fig. 16.1). By very finely mincing the tissue and by brief and light enzymatic digestion, muscle cells with their myoblasts attached are plated under standard culture conditions. After a couple of days, 


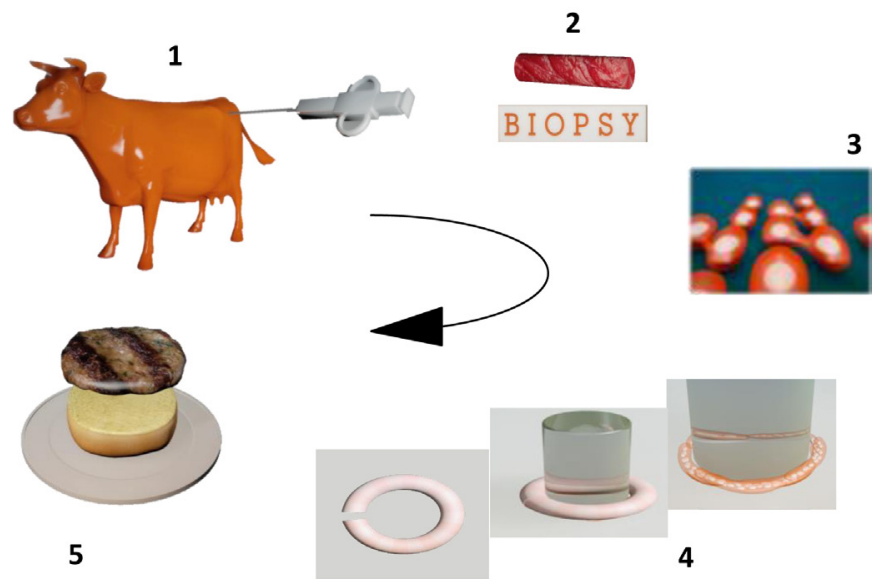

FIGURE 16.1 Process of culturing meat. 1, 2, Taking stem cells through a needle biopsy; 3, expanding number of cells through proliferation; 4, making tissues from myotubes that self-assemble around a central column so that they can attach to each other; 5 , putting together a patty using standard food technology.

the myoblasts migrate through the basal membrane of the muscle fiber and will start to proliferate. Depending on the purity of the biopsy, 95\% of the eventual cell population consists of CD56 positive myoblasts. Myoblasts can be replicated by standard cell culture methodology using serum-supplemented medium as "feed." Medium is a fluid that contains all necessary nutrients and vitamins for cells to grow. Myoblasts have sufficient but limited replicative capacity with a maximum of 45 doublings being reported in human cells (Hughes et al., 2015).

As myoblasts depend on attachment to a surface for their survival and growth, they are traditionally cultured in large numbers on the plastic bottom of culture flasks.

Once a sufficient number of myoblasts are obtained, the cells can be used in batches of 2 million cells to form a multicellular tissue in the form of a muscle fiber, the basic building block of a muscle and therefore of meat. To this end, the cells are submerged in a gel or scaffold that gives temporary support and allows the cells to merge and to connect to each other. By providing anchor points to the nascent tissue, the cells will align in between the anchor points and start to build up tension. This tension is the result of contractile proteins, but at the same time it is the strongest stimulus for the cells to express these proteins, thus entering a virtuous cycle. After approximately 3 weeks the muscle fibers are mature and can be harvested. They will be $2-3 \mathrm{~cm}$ long but less than $1 \mathrm{~mm}$ in diameter when they are harvested. Subsequently, the fibers are assembled into a patty to create a hamburger or any other presentation of minced meat. Standard food technology, including salt, seasoning, breadcrumbs, egg white powder, and a binder are used to make a firm patty that can be handled and cooked. 
The current technology has several disadvantages including limited scalability, repetitive handling with associated risk of contamination, and last but not least, inefficient use of resources, such as feedstock, disposable materials, energy, water, and manpower.

\section{TECHNICAL CONDITIONS FOR FEASIBILITY}

To turn cultured beef as proof of concept into a consumer product (Fig. 16.2) with the ambition to reduce resources, environmental and animal welfare impact, several conditions need to be met. The product can no longer contain animal materials other than the bovine myoblasts, cell production needs to be scaled to industrial proportions, tissue production will be automated, regulatory approval should be attained, and consumer acceptance has to be studied and guided. For the cultured beef to solve the environmental issues, production has to be resource and energy efficient.

\subsection{Eliminating Animal-Derived Materials}

Some of the currently used materials to make cultured beef are still animal derived and therefore not sustainable. They need to be replaced by either plantbased or synthetic biomaterials. In particular, fetal bovine serum (FBS) is traditionally used to culture cells. Ever since Burrows and Carrel were successful in cultivating mammalian tissue using serum (Carrel and Burrows, 1911), it has been a staple in cell culture. It is largely unknown which components of serum

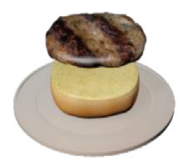

Scaling/automation cell and tissue production
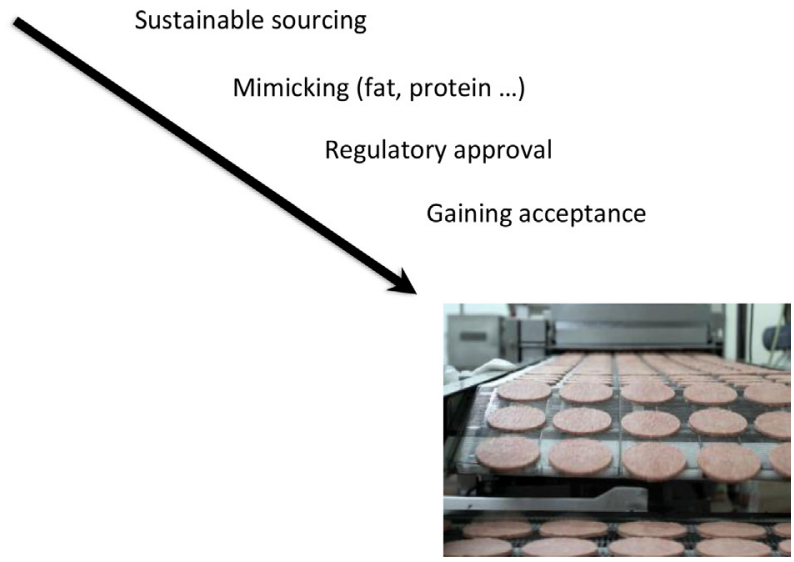

FIGURE 16.2 From proof of concept to a consumer product. 
are required to sustain in vitro cell growth, but it is most likely a specific balance between growth factors and growth inhibitors, in addition to metabolic regulators (Mannello and Tonti, 2007). There are several equally pressing reasons to eliminate FBS from the cell culture process. It is ill defined with significant batch-to-batch variability; the donor may have carried diseases; procurement is morally questionable and finally, there will not be enough serum around to sustain commercial meat production, especially if cultured meat will lead to decimation of livestock. A host of so-called serum-free culture media has been developed that is more or less specific to certain cell types. Some of them are chemically defined, indicating that their composition is completely documented and reproducible. For myoblasts, no serum-free medium is available yet. We have tested numerous conditions with existing serum-free media in combination with extra growth factors or cytokines, so far with limited success. It might be anticipated that it is particularly difficult to design a suitable serum-free medium for myoblasts, as these are typically grown in medium supplemented with $30 \%$ serum. Nevertheless, by building on the experience and success with developing serum-free medium for other cell types, it is likely that the same will eventually be true for myoblasts.

The other animal-derived material in cultured beef is bovine collagen mixed with Matrigel. This gel is used as temporary support for differentiating myoblasts to align, compact, and form a muscle fiber and is often referred to as matrix or scaffold (Langelaan et al., 2010). As for serum, this collagen/Matrigel mixture cannot be used for cultured beef production sustainably. It is a limited resource and batch-to-batch reproducibility is not guaranteed. Myoblasts, very similar to other mesenchymal cells, bind to and interact with specific extracellular proteins to solidify as a tissue. If mounted in a matrix of extracellular proteins and sugars, the cells will compact the matrix by assembling the proteins and sugars thereby effectively squeezing out excess water. Requirements for a synthetic or natural substitute of the animal-derived material are that there is a seemingly unlimited supply, that they are biocompatible and nontoxic when traces end up in the end product, that they form a gel of appropriate mechanical strength to support the cells in forming tissue and finally, and perhaps most importantly, are functional in that cells can interact and bind to compact the tissue. A large number of biobased and synthetic materials potentially fulfill three of these requirements. They typically consist of polymeric sugar chains that lack binding sites to which myoblasts can adhere. To solve the latter, the sugars are functionalized with short peptides such a cyclic arginine-glycine-aspartic acid (cRGD) thereby providing binding partners for cell membrane bound integrins (Sandvig et al., 2015). A wide array of such proteins are available to further optimize integrin-mediated binding and interaction of cells to a matrix of polymer sugar chains. Examples are alginate, derived from saltwater algae, chitins from shellfish, and cellulose from plants or trees. Alginates for instance are already widely used in food applications as binder or to make gels. Its vast supply from a natural source will secure the availability for large-scale meat production. 
Preliminary experiments in the laboratory of Maastricht University suggest that functionalized alginate has similar compacting properties as the collagen/Matrigel mix (unpublished data).

Synthetic biomaterials that are biocompatible and degradable include polylactic acid, polyglycolic acid, and polyurethanes. No food application using these materials has been described yet. For appropriate cell interaction they too would need to be functionalized with small peptides.

Given the wide range of possibilities and the encouraging success with some biomaterials, it seems likely that this problem can be solved in the foreseeable future.

\subsection{Mimicry}

The premise for cultured meat is that the consumer continues to expect meat as a readily available and affordable food choice and not a meat substitute with perceived lower quality. To what extent can cultured meat mimic livestock produced meat? Although this question directs primarily to sensory factors of meat, such as color, flavor, and tenderness, it is likely that the biochemical and structural composition of the engineered tissue needs to be similar to the natural product.

The color of currently formed muscle fibers is yellow, not pink or red. Culturing the cells at ambient oxygen conditions apparently suppresses myoglobin expression, responsible for most of meat's red color (USDA, 1998). Many studies have shown that myoglobin expression can be increased by culturing bovine muscle fibers under low oxygen conditions (Kanatous and Mammen, 2010). The results of Maastricht University in bovine myoblasts confirm those observations (unpublished results). Further metabolic studies on heme and iron incorporation have not been performed yet. Heme and iron are likely to contribute to the taste of meat as well.

The flavor of meat is the result of a highly complex composition of proteins, sugars, and aromates (Mottram, 1998). As the myoblasts are essentially the same cells as the ones producing livestock beef, we assume that the biochemical composition of the tissue can be made similar. If that is the case, the taste should be replicated as well. The proof-of-concept hamburger was made solely of muscle cells and an occasional fibroblast. Aromates residing in the fat fraction of meat were therefore largely lacking. To complement flavor, but also to add nutritional value and enhance the texture of meat, adipose tissue needs to be added to the product. Adipose tissue can be cultured from mesenchymal stem cells, adipose tissue-derived stem cells or perhaps even from myoblasts (Vettor et al., 2009). The most common cell source is the mesenchymal stem cell fraction, typically derived from a bone marrow aspirate. The ability to differentiate along the adipogenic line is one of the defining criterions for mesenchymal stem cells. A cocktail of dexamethasone, iso-butyl-methyl-xanthine (IBMX) and insulin is used to drive the differentiation. This cocktail is not compatible with 
food production. Adipogenic differentiation involves the activation of several transcription factors including PPAR- $\gamma$ and C/EBP- $\beta$. The dexa/IBMX/insulin mix activates these pathways at several levels. As free fatty acids (FFAs) are the natural ligands for PPAR- $\gamma$, several FFAs have been tested for their ability to induce adipogenesis in stem cells. Indeed, some of them have shown promising activity and are being tested in bovine preadipocytes derived from fat tissue. Maturation of adipose tissue into the typical white adipose tissue takes 2-3 months, much longer than muscle cells need to mature. However, with the goal of mimicking the entire tissue, adding fat tissue is mandatory. In addition to flavor, fat tissue contributes to the texture of meat. The proof-of-concept hamburger lacked fat and as a consequence had a dry mouth feel according to the limited number of tasters.

Like taste, texture or mouth feel is also the result of multiple features of meat, including tissue composition, microscopic and macroscopic tissue architecture, and ability to retain water and fat when cooked.

The formation of small pieces of muscle, such as in hamburgers or other forms of processed meat relies on the innate tendency of muscle cells and fibers to self-assemble in the previously mentioned matrix or scaffold. Histologically, the alignment and distribution of such self-assembled mature muscle fibers look very similar to muscle fibers in vivo. The bundles are maximally $1 \mathrm{~mm}$ in diameter and $2.5-\mathrm{cm}$ long with a distinct perimuscular fibrous sheet, resembling perimysium. The secondary structure of these bundles in larger bundles and eventually a full thickness muscle however cannot be formed on the basis of self-assembly alone. Such a tissue, a steak in principle, would require additional technology to provide the macroscopic architecture of the tissue, but more importantly it would need to contain a perfusable channel system to carry oxygen and nutrients into the tissue's center. The technologies to make those structures do exist but have not been applied yet to meat and will require substantial development.

The tissue-engineered muscle fibers have cross-striations, strongly suggesting that sarcomeres with appropriate actin and myosin complexes have formed.

Other cells may be required to accomplish full mimicry of meat. Skeletal muscle as our most metabolically active and oxygen demanding tissue during exercise is a highly vascularized tissue, mostly in the form of capillaries capable of gas and nutrient exchange. It seems unlikely on the basis of the small contribution of vascular cells to the total protein content of muscle that the vasculature contributes appreciably to taste or texture of meat. However, it is possible and even likely that vascular cells influence the maturation of skeletal muscle cells through paracrine activity. As an example, it has been shown that endothelial products enhance proliferation of skeletal myoblasts in vitro (Christov et al., 2007). Likewise, in heart muscle, enhanced neovascularization induces hypertrophy through paracrine effects involving a nitric oxide-dependent pathway (Tirziu et al., 2007).

The same might be true for neural cells. In vivo, muscle is innervated by sensory and somatic nerve cells that keep muscles in a state of continuous 
activity. Tissue engineered skeletal muscle spontaneously generates motor neuron endplates, but displays much more of these structures when myoblasts are cocultured with glial cells (Vianney and Spitsbergen, 2011). As a result, force generation of the artificial muscle upon electric stimulation is greatly increased.

Mutual interaction through a paracrine pathway or cell-cell contact might also exist between fat cells and skeletal muscle, providing an additional motivation to add fat tissue to the muscle.

Coculture of cells is experimentally challenging because the number of test conditions rapidly increase with increasing number of cell-types. It is also a technical challenge as most cell-types are specific in their nutritional needs. Finding the optimal medium and the optimal time to introduce new cell types in the culture requires extensive testing. However, if most cell interactions are in fact based on paracrine influences, the factors involved might be isolated and used without using the original cell source in coculture.

Sensory experiments including tasting panels will finally determine the success of mimicry. To feed these tasting panels, production needs to be scaled up.

Finally, recreating muscle tissue in all of its complexity may not be sufficient if the aging process after death of the tissue is not similar to livestock meat. Regarding aging of conventional meat, a long storage time of beef (at least 14 days) in cooling conditions is recommended to obtain an acceptable final tenderness and flavor of meat. Many studies have shown that the meat tenderization process is complex and is based on the extent of proteolysis of key target skeleton proteins within muscle fibers and the alteration of muscle structure due the sequential actions of many enzymes. More precisely, after slaughter of farm animals, muscle fibers go into rigor mortis due to protein contraction and the muscle is tough. The extent of this process in the case of cultured beef is still unknown and is likely to be different due to different harvest conditions of the muscle, being just ischemia in cultured meat and a sequence of death-related events in vivo, such as release of catecholamines and stress factors. Subsequently, as the aging process occurs in muscle from farm animals, aerobic metabolism declines with the decreasing oxygen supply and therefore, glycogen is converted into lactic acid inducing a decline in $\mathrm{pH}$ to 5.4-5.8. The $\mathrm{pH}$ and temperature should decline within a precise window to achieve optimal palatability of meat (Thompson, 2002). It is as yet unknown if this process is reproduced in the ischemic cultured beef. In the case of conventional meat, postmortem protein breakdown is caused by the proteolytic action of different endogenous muscle enzyme groups during carcass storage. However, the importance of the different groups of muscle peptidases in this process is still a matter of controversy. Indeed, the calpain system with its associated inhibitors (calpastatin) was considered to be the primary system responsible for meat tenderization and the action of this system is still under study (Lian et al., 2013). More recently, the onset of apoptosis, which controls the cell death process and the associated degradation of structural proteins, was thought to be important as well, but this process is extremely complex with a great number of 
molecular actors involved and it is therefore not completely understood (Ouali et al., 2013). Researchers are still working to understand these mechanisms to better predict the quality of conventional meat, and therefore, the only way to reproduce these events is to create a product that is as close a mimic of livestock meat as possible.

\subsection{Scaling of Production}

Myoblasts, like most mesenchymal cells, are contact dependent meaning that they only survive and grow when attached to a surface. Traditionally, this type of cell culture is performed in Petri dishes or cell culture flasks, where the cells adhere to the plastic bottom and are covered with medium. This geometry provides a poor surface-to-volume ratio, which is inefficient and cannot be scalable to industrial proportions. In contrast, bacteria and yeast grow in suspension and are typically cultured in large 25,000 L stirring bioreactors. To grow myoblasts in suspension, microcarriers are introduced. These are small spheres $(100 \mu \mathrm{m}$ in diameter) that are suspended in medium and provide the necessary surface for myoblasts. A large number of microcarriers with specific composition and characteristics are available and most of them are tested on mesenchymal stem cells. These generally positive results should be translatable to myoblasts given the similarities between mesenchymal stem cells and myoblasts. Preliminary experiments focused on this translation show that myoblasts indeed grow well on microcarriers suspended in medium in stirrer flasks as well as in a $1.5 \mathrm{~L}$ stirring bioreactor (unpublished results). Optimization with respect to type of microcarriers, seeding density, medium choice, medium change, etc. will require substantial additional work but is technically feasible (Moritz et al., 2015). From the 1.5 L bioreactor, the process still has to be scaled to $25,000 \mathrm{~L}$, currently the biggest stirring bioreactor available. Scaling up from a 1.5 to $5 \mathrm{~L}$ has been done for mesenchymal stem cells (Rafiq et al., 2013) and it is assumed that from there up is mostly determined by technical adjustments to provide adequate content mixing and temperature control. The scaled bioreactors from $5 \mathrm{~L}$ up to $25,000 \mathrm{~L}$ are commercially available, albeit that they are optimized for bacterial or yeast culture.

Although scaling of cell production is the biggest challenge, subsequent tissue production needs to be scaled as well. Currently, the tissues are assembled by manual pipetting, which is very laborious, expensive, and susceptible to contamination. Automation in a closed, sterile environment is likely the methodology that is required for scaling up this part of the process. In tissue engineering for medical purposes, similar steps have already been made to the level of a fully automated cell harvest, cell production, and tissue assembly with full quality control of every sequence (Groeber, 2015). At the stage of tissue production, cell density is much higher than in cell production so that less space and medium is required to grow the tissues.

With scaling of cell and tissue production, supply of medium will become a critical issue. Growth medium for mammalian cells is expensive and the 
production is proportioned to the demand for scientific experiments and medical applications. For large-scale meat production, this supply needs to increase by orders of magnitude. Components of medium are plant-based or produced in microorganisms. As an alternative, production of proteins and sugars by algae has been discussed, but not implemented yet. The biotechnology industry to produce the components has to scale according to the projected increase in demand when cultured meat production is scaled. From a resource and technology point of view this is likely feasible. Potential bottlenecks, such as the availability of sufficiently qualified personnel, need to be identified and dealt with in a timely fashion.

\subsection{Efficiency}

For cultured beef to serve as a solution for threatened food security and environmental burden of livestock, the production needs to be more efficient than a cow. This means that less resources, such as feedstock, fresh water, land, and energy will be used to produce the same or preferably increased amounts of beef. Cell culture has not been efficient up until now, mostly because there was no need for it. The goal of mammalian cell culture was mostly scientific or to address a medical problem where being green was either ignored or at best handled as secondary objective. Efficiency can potentially be achieved by changing medium composition, adjusting bioreactor processes, including recycling of materials and last but not least, by scaling up. Estimates of efficiency of the current small-scale process are not available and are not very useful. Based on extensive modeling and using many assumptions, which are discussed in the scientific community, preliminary life cycle analyses have been performed with variable outcome, especially when it comes to energy consumption. The most favorable resource saving came out of one of the earliest studies, where the assumption was that algae products could be used to feed myoblasts in culture to produce beef. That study resulted in a predicted saving of roughly $90 \%$ water and land usage and 60\% energy (Tuomisto and Teixeira de Mattos, 2011). Another, more recent study, predicts that culturing meat does not save energy but may lead to increased energy expenditure while still preserving water and land supply (Mattick et al., 2015).

The uncertainties in these models are large and we therefore have to wait for scaled production and improvements in technology, so that these models can gain a higher level of predictability.

\section{NUTRITIONAL VALUE}

It is the goal of culturing beef to produce the same tissue as livestock beef, suggesting that the nutritional value is going to be the same. There will remain differences though. Skeletal muscle cells and adipocytes are capable of making many proteins, fatty acids, growth factors, and cytokines. Some of the regular 
constituents, such as vitamin B12 however are not produced by the cells but are taken up from the environment, in vivo from the blood. An easy fix would be to add vitamin B12 to the growth medium. There are other factors that are taken up from the environment that would need to be supplied to the medium to get it into the tissue. For efficiency reasons, future studies will be directed to which of those factors are necessary, which are not and which might actually be harmful to the consumer. Epidemiologic studies point at an association between meat eating and cardiovascular disease and colon cancer. If the causal factors are in meat itself_-some of them are likely to appear during cooking — can be identified and if they are not obligatory produced by muscle or fat cells, there is an opportunity to culture meat devoid of these factors thereby creating a healthier product.

\section{SAFETY}

Again under the assumption that cultured beef is very similar to livestock beef, the product itself should have no particular safety risks. However, the production method is radically different and some aspects therefore need to be considered. On the positive side, the starting sample from which the myoblasts are harvested is very small and obtained by sterile procedure. Because of its small size, it can be easily ascertained that it is free of microorganisms and parasites. During the production phase, the cells and tissues have to be under aseptic conditions or microorganisms will overgrow the culture. Other toxic conditions are equally unlikely to sustain survival and growth of cells in culture, so the cells serve as their own coal mine parakeets. A substance, such as phenol that is typically present in cell culture medium to detect a drop in $\mathrm{pH}$, can easily be omitted from the medium.

On the negative side, there is a potential for genetic instability of cells due to the high number of proliferations that are required to expand the cell number. In other words, cancerous cells might develop and hide in the vast amount of cells while going unnoticed. Sporadic cancerous cells are probably harmless. They are dead when the meat is ready to be eaten and even if they would be still alive, they would be killed in our digestive system. However, it is prudent to regularly control for presence of gene or chromosome artifacts on a per batch basis, as is the policy in producing stem cells for medical application. This should be part of quality control.

\section{ACCEPTANCE}

Throughout evolution, prehumans and human beings have been eating meat among other types of food simply because humans are omnivores. At the beginning of their history, humans were scavengers and/or hunters (Speth, 1989), since their digestive systems were well equipped (and are still well equipped) to make full use of animal foods. By contrast, human beings have much shorter 
digestive systems than herbivores and don't have the specialized organs to digest cellulose. Therefore, human beings cannot make use of plants and grass. However, eating meat from herbivores is an efficient way for human beings to indirectly valorize plants, grass and any type of natural pasture.

Some evidence shows that our prehuman ancestors were eating meat and that human physiology was adapted to a diet with a regular consumption of meat as early as 1.5 million years ago (Dominguez-Rodrigo et al., 2012). Since then, human beings have always more or less consumed meat from different types of animals, and this consumption was thought to be associated with the development of a larger and a more elaborated brain. Meat consumption was also associated with social organization and geographic movements of human populations, which were always in expansion before sedentary lifestyle. Other argued that meat has several nutritional advantages (for instance, a good amino acid profile, and a high level in vitamin B12 unlike plants), which may explain why humans eat a lot of meat. In fact, it was demonstrated that whenever and wherever it was ecologically possible, hunter-gatherers used to consume a lot of animal foods (about $45-65 \%$ of energy). More precisely, about $73 \%$ of the worldwide hunter-gatherer people derived $>50 \%$ of their subsistence from animal foods, whereas only $14 \%$ of these societies derived $>50 \%$ of their subsistence from plants (Cordain et al., 2000). Today, about $90 \%$ of human beings eat meat and eating meat is often associated to a pleasure. In summary, humanity has been and is still characterized by a high reliance on animal-based foods.

Throughout history, limited availability, nutritional needs, as well as cultural factors were thus the main drivers of meat consumption (Fig. 16.3A). Nowadays, thanks to the development of the economic world, and especially in developed countries where meat is readily available, the main factors which affect any food product purchase and consumption (Fig 16.3B) are sensory factors (mainly color, tenderness, and flavor in the case of meat), psychological factors (including cultural factors and lifestyle) but also marketing factors, such as price, brand, label, and others (Font-I-Furnols and Guerrero, 2014). Among psychological factors, new issues, such as moral concerns around animal welfare (De Backer and Hudders, 2015) and carbon footprint were raised (Scollan et al., 2011). Thanks to these contradictory drivers, the meat substitutes market is developing into consumer's products which are not meat, but which look like meat in terms of shape, visual aspect, and nutritional supply. However, for any type of food of different quality levels, guarantee of hygiene and safety are the first drivers of purchase and consumption at the consumer level, followed by price (Hocquette et al., 2013). So, the acceptance of any new food product (including cultured meat) will primarily depend on these three main factors: hygiene, safety, and an affordable price.

Once guaranteed safety and an affordable price will be achieved, consumers will either accept or reject cultured meat depending on psychological and sensory factors. Assuming that sensory quality traits of meat will be totally reproduced by cultured meat, some researchers have examined psychological factors, 
(A)

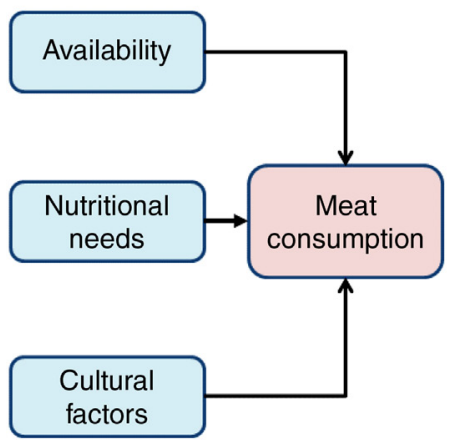

(B)

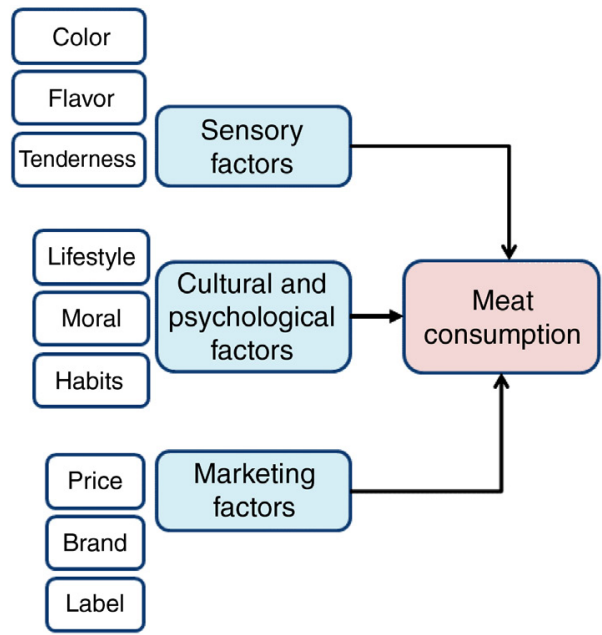

FIGURE 16.3 Main factors affecting meat consumption during the human history (A) and since the development of the economic world (B). In (B) only some examples of factors are given at the second level (white boxes). The main factors described in (B) can be extrapolated for all types of meat substitutes including cultured beef. (Part B, adapted from Font-I-Furnols, M., Guerrero, L., 2014. Consumer preference, behavior and perception about meat and meat products: an overview. Meat Sci. 98, 361-371.)

referring to the product as "artificial meat." Initial reactions of consumers about artificial meat are feelings of disgust and considerations of unnaturalness. After thinking, consumers cannot see many direct personal benefits but perceive global societal benefits relating to the environment and global food security. However, these benefits are perceived as uncertain especially regarding safety and health, with possible adverse societal consequences dealing with loss of farming, eating traditions, and rural livelihoods. Further reflection pointed out concern about risk governance and control, and need for regulation and proper labeling (Verbeke et al., 2015).

To better understand consumers' reactions regarding artificial meat, a total of 1890 educated people (mainly scientists and students) were interviewed worldwide (Hocquette et al., 2015). A majority of the respondents believed that "artificial meat" was feasible and realistic (between 54\% and 75\%) and that 48-81\% think that the meat industry is really facing important problems related to the protection of the environment, animal welfare or inefficient meat production to feed humanity. Thirty to $45 \%$ of respondents did not think that "artificial meat" will be the solution to solve the aforementioned problems and $24-42 \%$ believe that artificial meat will be healthy and tasty. Forty-one to $65 \%$ of respondents wished to continue to eat meat while accepting to consume less meat. Only a minority (from $5 \%$ to $11 \%$ ) would recommend or accept to eat in vitro meat instead of meat produced from farm animals and 49-64\% believed that consumers would not accept artificial meat in the future. It was speculated that the 
apparent contradictory answers expressed the fact that people trust scientists to develop artificial meat that is potentially useful in the future, but have also concern for their own health because they are not convinced that artificial meat will be tasty, safe, and healthy enough to be accepted by consumers. More generally, some authors mentioned that technophobia may be a reason to reject artificial meat, meat from genetically modified, and meat from cloned organisms even if they are different products (Bonny et al., 2015a). Cultural factors and framing of the questions certainly play a role in surveys. In a Dutch survey among a 15,000 people cross-section of the general population, $23 \%$ responded "yes" and 29\% "yes, probably" to the question "would you buy cultured meat at least once to try, if it were available in the supermarket" (http://www.flycatcherpanel. nl/news/item/nwsA1697/media/images/Resultaten_onderzoek_kweekvlees. pdf, published 2013). Although these initial studies are useful and insightful, it is fair to say that the eventual success can only be determined after market introduction.

Other authors observed that the only meat substitutes that are currently widely available to consumers are meat replacement products manufactured from plant proteins and mycoproteins. In the future, new products may be on the market, such as cloned and genetically modified meat, meat produced through agroecological livestock systems (Dumont et al., 2013), proteins from insects and cultured meat produced from stem cells. Therefore, the market of protein products is likely to become more complex with many products competing with each other. Consequently, the future market of cultured meat produced from stem cells has many new potential competitors (Bonny et al., 2015a). Indeed, according to one author, "artificial" meat will be considered to be ethical only if it is more effective at reducing conventional animal meat consumption than plant-based analogs (Laestadius, 2015).

\subsection{Future Possibilities With Cultured Meat}

Livestock meat comes in many varieties from different parts of the body. Cultured beef can be as variable and probably even more so than the livestock correlate. While a few companies are preparing the minced product for the market, further scientific and technical endeavors may focus on culturing whole cuts, such as a steak. A steak is a more complex structure with feeding channels (blood vessels), organized fibrous tissue, various degrees of marbling and perhaps even a bone. Building such a complex structure will involve some sort of free form fabrication, such as 3D printing. 3D printing of cells and biomaterials is possible but still needs to be refined to make complex multicell, multimaterial tissues. If established one day, the technology is potentially versatile in that every imaginable macroscopic architecture can be theoretically generated to mimic the classic pieces of muscles coming from an animal.

Muscle can be cultured from all animals that have myoblasts in their skeletal muscles. Pork and chicken are the most likely immediate candidates, but fish 
is definitely possible as well. For each of these species, different justifications, such as animal welfare or maintenance of biodiversity can be formulated to start culturing their muscle.

Therefore, new products can be envisioned by mixing myoblasts from two of more species or taking myoblasts from exotic species, hitherto unknown products can be generated. The very imaginative and fun In Vitro Meat Cookbook that was launched in 2014 suggest a wide range of new products from cultured meat, illustrating that our current concept of meat may be challenged in the future. Perhaps more interesting is the potential creation of healthier muscle products that contain for instance less fat or more polyunsaturated fatty acids, such as $\omega$-3 fatty acids, which reduce the risk of cardiovascular disease.

\section{DISCLAIMER}

This chapter was written by two authors whose beliefs concerning cultured beef are totally opposed. Mark Post has previously published more enthusiastic papers (Post, 2012) while Jean-François Hocquette has taken a more critical stance (Bonny et al., 2015b; Hocquette, 2016). The aim of the collaboration between these two views is to describe the state of the art in the most objective way.

\section{REFERENCES}

Bonny, S.P.F., Gardner, G.E., Pethick, D.W., Hocquette, J.F., 2015a. What is artificial meat and what does it mean for the future of the meat industry. J. Integr. Agric. 14, 8.

Bonny, S.P.F., Gardner, G.E., Pethick, D.W., Hocquette, J.F., 2015b. What is artificial meat and what does it mean for the future of the meat industry? J. Integr. Agric. 14, 255-263.

Carrel, A., Burrows, M.T., 1911. Cultivation of tissues in vitro and its technique. J. Exp. Med. 13, 387-396.

Christov, C., Chretien, F., Abou-Khalil, R., Bassez, G., Vallet, G., Authier, F.J., Bassaglia, Y., Shinin, V., Tajbakhsh, S., Chazaud, B., Gherardi, R.K., 2007. Muscle satellite cells and endothelial cells: close neighbors and privileged partners. Mol. Biol. Cell 18, 1397-1409.

Cordain, L., Miller, J.B., Eaton, S.B., Mann, N., Holt, S.H., Speth, J.D., 2000. Plant-animal subsistence ratios and macronutrient energy estimations in worldwide hunter-gatherer diets. Am. J. Clin. Nutr. 71, 682-692.

De Backer, C.J., Hudders, L., 2015. Meat morals: relationship between meat consumption consumer attitudes towards human and animal welfare and moral behavior. Meat Sci. 99, 68-74.

Dominguez-Rodrigo, M., Pickering, T.R., Diez-Martin, F., Mabulla, A., Musiba, C., Trancho, G., Baquedano, E., Bunn, H.T., Barboni, D., Santonja, M., Uribelarrea, D., Ashley, G.M., Martinez-Avila Mdel, S., Barba, R., Gidna, A., Yravedra, J., Arriaza, C., 2012. Earliest porotic hyperostosis on a 1.5-million-year-old hominin, olduvai gorge, Tanzania. PLoS One 7, e46414.

Dumont, B., Fortun-Lamothe, L., Jouven, M., Thomas, M., Tichit, M., 2013. Prospects from agroecology and industrial ecology for animal production in the 21st century. Animal 7, 1028-1043.

FAO, 2011. World Livestock 2011. Livestock in food security. FAO publications.

Font-I-Furnols, M., Guerrero, L., 2014. Consumer preference, behavior and perception about meat and meat products: an overview. Meat Sci. 98, 361-371.

Groeber, F., 2015. Available from: http://www.igb.fraunhofer.de/en/competences/tissue-engineering/tissue-models/skin-from-the-factory.html 
Hocquette, J.F., 2016. Is in vitro meat the solution for the future? Meat Sci. 120, 167-176.

Hocquette, J.F., Jacquet, A., Giraud, G., Legrand, I., Sans, P., Mainsant, P., Verbeke, W., 2013. Quality of food products and consumer attitudes in France. In: Klopcic, M., Kuipers, A., Hocquette, J.F. (Eds.), Consumer attitudes to food quality products. Wageningen Academic Publishers, Wageningen.

Hocquette, A., Lambert, C., Singuin, C., Peterolff, L., Wagner, Z., Bonny, S.P.F., Lebert, A., Hocquette, J.F., 2015. Educated consumers don't believe artificial meat is the solution to the problems with the meat industry. J. Integr. Agric. 14, 11.

Hughes, D.C., Stewart, C.E., Sculthorpe, N., Dugdale, H.F., Yousefian, F., Lewis, M.P., Sharples, A.P., 2015. Testosterone enables growth and hypertrophy in fusion impaired myoblasts that display myotube atrophy: deciphering the role of androgen and IGF-I receptors. Biogerontology 17, 619-639.

Kanatous, S.B., Mammen, P.P., 2010. Regulation of myoglobin expression. J. Exp. Biol. 213, 2741-2747.

Laestadius, L.I., 2015. Public perceptions of the ethics of in-vitro meat: determining an appropriate course of action. J. Agric. Environ. Ethics 28, 18.

Langelaan, M.L., Boonen, K.J., Polak, R.B., Baaijens, F.P., Post, M.J., Van Der Schaft, D.W., 2010. Meet the new meat: tissue engineered skeletal muscle. Trend. Food Sci. Technol. 21, 7.

Lian, T., Wang, L., Liu, Y., 2013. A new insight into the role of calpains in post-mortem meat tenderization in domestic animals: a review. Asian Aust. J. Anim. Sci. 26, 11.

Mannello, F., Tonti, G.A., 2007. Concise review: no breakthroughs for human mesenchymal and embryonic stem cell culture: conditioned medium, feeder layer, or feeder-free; medium with fetal calf serum, human serum, or enriched plasma; serum-free, serum replacement nonconditioned medium, or ad hoc formula? All that glitters is not gold! Stem Cells 25, 1603-1609.

Mattick, C.S., Landis, A.E., Allenby, B.R., Genovese, N.J., 2015. Anticipatory life cycle analysis of in vitro biomass cultivation for cultured meat production in the United States. Environ. Sci. Technol. 49, 11941-11949.

Moritz, M.S.M., Verbruggen, S.E.L., Post, M.J., 2015. Alternatives for large-scale production of cultured beef. J. Integr. Agric. 14, 3.

Motohashi, N., Asakura, A., 2014. Muscle satellite cell heterogeneity and self-renewal. Front. Cell Dev. Biol. 2, 1.

Mottram, D.S., 1998. Flavour formation in meat and meat products: a review. Food Chem. 62, 9.

Ouali, A., Gagaoua, M., Boudida, Y., Becila, S., Boudjellal, A., Herrera-Mendez, C.H., Sentandreu, M.A., 2013. Biomarkers of meat tenderness: present knowledge and perspectives in regards to our current understanding of the mechanisms involved. Meat Sci. 95, 854-870.

Post, M.J., 2012. Cultured meat from stem cells: challenges and prospects. Meat Sci. 92, 297-301.

Rafiq, Q.A., Brosnan, K.M., Coopman, K., Nienow, A.W., Hewitt, C.J., 2013. Culture of human mesenchymal stem cells on microcarriers in a 51 stirred-tank bioreactor. Biotechnol. Lett. 35, $1233-1245$.

Sandvig, I., Karstensen, K., Rokstad, A.M., Aachmann, F.L., Formo, K., Sandvig, A., Skjak-Braek, G., Strand, B.L., 2015. RGD-peptide modified alginate by a chemoenzymatic strategy for tissue engineering applications. J. Biomed. Mater. Res. A 103, 896-906.

Scollan, N.D., Greenwood, P.L., Newbold, C.J., Yanez Ruiz, D.R., Shingfield, K.J., Wallace, R.J., Hocquette, J.F., 2011. Future of research priorities for animal production in a changing world. Anim. Prod. Sci. 51, 5.

Seale, P., Sabourin, L.A., Girgis-Gabardo, A., Mansouri, A., Gruss, P., Rudnicki, M.A., 2000. Pax7 is required for the specification of myogenic satellite cells. Cell 102, 777-786. 
Speth, J.D., 1989. Early hominid hunting and scavenging: the role of meat as an energy source. J. Hum. Evol. 18, 14.

Thompson, J., 2002. Managing meat tenderness. Meat Sci. 62, 295-308.

Tirziu, D., Chorianopoulos, E., Moodie, K.L., Palac, R.T., Zhuang, Z.W., Tjwa, M., Roncal, C., Eriksson, U., Fu, Q., Elfenbein, A., Hall, A.E., Carmeliet, P., Moons, L., Simons, M., 2007. Myocardial hypertrophy in the absence of external stimuli is induced by angiogenesis in mice. J. Clin. Invest. 117, 3188-3197.

Tuomisto, H.L., Teixeira De Mattos, M.J., 2011. Environmental impacts of cultured meat production. Environ. Sci. Technol. 45, 6117-6123.

USDA, F.S. A. I. S. 1998. The color of meat and poultry. Available from: http://dwb.unl.edu/teacher/ nsf/c10/c10links/www.fsis.usda.gov/oa/pubs/mpcolor.htm

Verbeke, W., Marcu, A., Rutsaert, P., Gaspar, R., Seibt, B., Fletcher, D., Barnett, J., 2015. 'Would you eat cultured meat?' Consumers' reactions and attitude formation in Belgium, Portugal and the United Kingdom. Meat Sci. 102, 49-58.

Vettor, R., Milan, G., Franzin, C., Sanna, M., De Coppi, P., Rizzuto, R., Federspil, G., 2009. The origin of intermuscular adipose tissue and its pathophysiological implications. Am. J. Physiol. Endocrinol. Metab. 297, E987-E998.

Vianney, J.M., Spitsbergen, J.M., 2011. Cholinergic neurons regulate secretion of glial cell linederived neurotrophic factor by skeletal muscle cells in culture. Brain Res. 1390, 1-9. 